\title{
TRANSFER OBCYCH REALIÓW NA PRZYKŁADZIE TEKSTU POPULARNONAUKOWEGO DEFINICJE I PODSTAWOWE PROBLEMY
}

\footnotetext{
Zarys treści. Termin "obce realia" nie doczekał się jeszcze w Polsce jednolitej i zadowalającej definicji. Większość badaczy zgadza się, że należy go ściśle powiązać z tym, co rozumiemy jako kulturę danego kraju. Elementy nacechowane kulturowo stają się zatem synonimami obcych realiów i często wypada mówić raczej o ich transferze (przeniesieniu i/lub tłumaczeniu) niż tłumaczeniu. Tekst popularnonaukowy jest dla tłumacza szczególnym wyzwaniem: może bowiem okazać się, że realia stanowiące $w$ tekście oryginalnym wiedzę implicytną (zakładaną przez autora u odbiorcy oryginału), dla czytelnika przekładu staną się przeszkodą w lekturze tekstu, który z założenia kierowany jest do niespecjalistów.
}

$\mathrm{T}$ ermin „obce realia”, powszechnie używany zarówno przez teoretyków, jak i praktyków tłumaczenia, nie ma jeszcze jednolitej i w pełni sformułowanej definicji. Roman Lewicki w swej książce, na której oprę znaczną część moich dzisiejszych rozważań (Lewicki 2000), zajmuje się między innymi obcymi realiami i przyznaje, że „panuje co do istoty i zakresu tych nazw znaczny chaos pojęciowy" (Lewicki 2000: 49). Przyjrzyjmy się zatem istniejącym definicjom tego pojęcia; przyjęcie bowiem w całości lub częściowo którejś z nich determinuje zakres jednostek, które badamy jako „obce realia”, determinuje także zakres problemów traduktologicznych, którym tłumacz jest zmuszony stawić czoło.

Realia zawarte w tekście stają się „obce” z chwilą, gdy tekst oryginalny zostaje poddany procesowi tłumaczenia. Przeniesienie bowiem tekstu do innej kultury i oddanie go w ręce nowego, odmiennego kulturowo kręgu 
odbiorców powoduje, iż pewne jednostki zawarte w tekście wyjściowym mogą być odebrane przez nowego czytelnika jako „sygnały obcości” (Lewicki 2000: 45). Widzimy zatem, że pojęcie „obcych realiów” pozostaje ściśle związane z tym, co rozumiemy jako „kulturę” danego narodu. Oczywiście nie będę w tym momencie analizował pojęcia kultury z punktu widzenia etnografii, ograniczę się jedynie do zwrócenia uwagi na dużą liczbę jednostek, które możemy zakwalifikować jako „obce realia”. Lewicki twierdzi, iż wszystkie elementy, które stanowią o odrębności, specyfice danej kultury, które ją charakteryzują w stosunku do kultury odbiorców przekładu, muszą aktywizować kategorię obcości w tekście przekładu. Jakie to mogą być elementy? Ke Ping w swym artykule Cultural Presuppositions and Misreadings (1999) wymienia następujące zjawiska współtworzące kulturę: system ekonomiczny, środowisko naturalne, sztuka, technologia, system społeczny, relacje rodzinne, polityka i prawo, zwyczaje, historia narodowa, religia, folklor, mentalność, całość zjawisk związanych z językiem i wiele innych. Tworzą one odrębną kulturę, która w tekście przekładu pozostawia swoiste „ślady”; ślady te możemy nazwać „obcymi realiami”. Również Marianne Lederer (1994: 122-126), Jerzy Pieńkos (2003: 183-185) i Zhang Xinmu (1999) zwracają uwagę na elementy nacechowane kulturowo, które sprawiają duże trudności w procesie tłumaczenia. I choć nie nazywają oni tych jednostek wprost „obcymi realiami”, z pewnością możemy je jako takie zakwalifikować, gdyż wszystkie współtworzą specyfikę kultury danego narodu. I tak Lederer wymienia: zwyczaje żywieniowe, religijne, folklorystyczne, sztukę, literaturę, muzykę i szeroko pojęte obyczaje; Pieńkos dorzuca do powyższej listy nazwy tańców, zwyczajów regionalnych, aluzje historyczne i erudycyjne, a Xinmu dodaje (i jest to jego termin) „oznaki tożsamości” [signes sociaux]: nazwy stopni wojskowych, odznaczeń, mark fabrycznych, formuły grzecznościowe, nazwy gier oraz rytów.

Dla moich dzisiejszych rozważań głównym punktem odniesienia jest klasyfikacja zaproponowana przez Romana Lewickiego, choć zakres odnoszonych do klasy obcych realiów jednostek rozumiem w sposób szerszy niż Lewicki. Otóż elementy, które w tekście przekładu zawierają sygnały obcości, nazywa on „potencjalnymi nośnikami obcości”. Mogą to być w jego rozumieniu (Lewicki 2000: 45) cechy struktury tekstu (a więc typ tekstu lub cechy typu tekstu, co występuje np. w tłumaczeniu nekrologów) oraz jednostki tekstu, do których zalicza on: nazwy własne, adresatywy, barbaryzmy, elementy słowotwórcze w ramach jednostek leksykalnych, frazemy, jednostki morfologiczne i składniowe, elementy graficzne oraz nazwy realiów. Widzimy zatem, że Lewicki ogranicza zakres jednostek określanych 
jako „obce realia”: są nimi obiekty, które nie należą do systemu języka docelowego (dalej - JD), w konsekwencji zaś są typowe dla języka wyjściowego (dalej - JW). Przyznaje on jednak, iż „niejasne jest, czy mają one [tj. nazwy realiów] oznaczać denotaty obce doświadczeniom nosicieli JP, czy pojęcia (nawet gdy denotaty są znane nosicielom JP), a także czy i na ile istotne jest kryterium bezekwiwalentności" (Lewicki 2000: 48-50; JP = język przekładu - A. T.).

Jeśli porównamy klasyfikację Lewickiego z wyróżnieniami dokonanymi przez Lederer, Pieńkosa czy Xinmu, to zauważymy, że w rzeczywistości mają one ze sobą wiele wspólnego, a podstawowe różnice dotyczą stosowanej terminologii. Niektóre nazwy np. dań lub odznaczeń wojskowych rzeczywiście są typowe tylko dla danego kraju i z pewnością można je umieścić pod hasłami takimi jak: nazwy własne, elementy graficzne itd.; tego typu nazwy będą częściej spełniały kryterium bezekwiwalentności. Jednakże elementy tekstu, takie jak aluzje historyczne czy erudycyjne - z pewnością stanowią bardziej skomplikowany problem; po pierwsze dlatego, że bezekwiwalentność często ich nie dotyczy (możemy bowiem przetłumaczyć np. „Révolution du 1789” jako „Wielką Rewolucję Francuską” czy „Le philosophe de Ferney veut <écraser l'infâme>” jako "Filozof z Ferney chce <zmiażdżyć niegodziwca>"), w tym wypadku jednak będą to zawsze denotaty należące do historii innego narodu; po drugie dlatego, iż często wydarzenia historyczne są wspólne dla kilku społeczeństw i narodów (i tak np. aluzja do wojny francusko-algierskiej będzie stanowiła denotat obcy doświadczeniom Polaka, ale nie Francuza czy Algierczyka). Innym problemem są denotaty, które „przywędrowały” do JD z innej kultury, ale zostały zasymilowane i zamieszczone w słownikach JD. Wydaje się, iż denotaty takie nie mogą być nazywane „obcymi” i z tego też powodu nie mogą stanowić obcych realiów.

Dokonując podsumowania przytoczonych powyżej zakresów definicji wyrażenia „obce realia”, nazwą tą obejmuję jednostki wskazane przez Pieńkosa, Lederer, Xinmu oraz te jednostki, które Lewicki określa jako „potencjalne nośniki obcości”. Właśnie takie „całościowe” rozumienie tego terminu pojawia się u Krzysztofa Hejwowskiego (2004: 71-72). Tenże autor używa terminu „realia” na określenie „takich elementów tekstu, które w sposób szczególny łączą się z kulturą danego kraju”: imiona własne, nazwy i zwroty związane z organizacją życia w kraju kultury wyjściowej, obyczajami i przyzwyczajeniami, cytaty i aluzje mające związek z literaturą danego kraju, aluzje do historii kraju i do innych sfer kultury, takich jak muzyka, film, malarstwo itd. 
W tytule niniejszego artykułu zdecydowałam się na użycie słowa „transfer” zamiast „tłumaczenie”. „Transfer” rozumiem i jako 'przeniesienie’, i jako 'tłumaczenie', natomiast trudno mówić o 'tłumaczeniu' w przypadku nazw własnych czy elementów graficznych. W tej części artykułu pragnę zająć się bliżej wybranymi zagadnieniami transferu obcych realiów, zaczerpniętymi z dokonanego przeze mnie tłumaczenia części książki popularnonaukowej La religion en France de la fin du XVIII siècle à nos jours autorstwa Gérarda Cholvy'ego. Dla odbiorcy polskiego obce realia zwarte w tekście korpusu to te elementy tekstu, które odsyłają do historii, kultury, geografii, systemu językowego Francji i Francuzów (a także do realiów obcych innych niż „francuskie”: afrykańskich, angielskich, kanadyjskich, które są zawarte w tekście). Podzieliłam je na następujące kategorie: nazwy własne, tytuły dzieł literackich, dokumentów, aluzje historyczne i erudycyjne.

Nie będę w tym miejscu rozważać różnych technik tłumaczeniowych, które znajdują zastosowanie w transferze obcych realiów. Jest to zagadnienie samo w sobie obszerne i z pewnością wymagałoby osobnego omówienia. W dalszej części artykułu ograniczę się do omówienia celowych działań tłumacza, który świadomie wprowadza do tekstu przekładu obce realia bądź też zwiększa natężenie obcości w wybranych realiach.

Lewicki uważa (2000: 133-137), że fakultatywne wprowadzanie do tekstu przekładu obcych realiów ma potrójne uwarunkowanie:

1) dążenie do pozostania wiernym oryginałowi; unikanie naturalizacji;

2) dążenie do poszerzenia wiedzy czytelnika o obcej kulturze (funkcja poznawcza tekstu odgrywa w tym wypadku dominującą rolę);

3) dążenie do egzotyzacji tekstu wyjściowego (dalej - TW).

Zauważmy, że o ile pierwszy element mógłby stanowić osobne studium, o tyle dwa pozostałe wydają się ze sobą ściśle powiązane. Czemu bowiem miałoby służyć celowe wprowadzanie do tekstu obcych realiów w formie zapożyczeń, form zleksykalizowanych bądź neologizmów słowotwórczych tworzonych od obcych nazw własnych, jeśli nie chęci wprowadzania czytelnika tekstu docelowego (dalej - TD) w bliższy kontakt z inną kulturą, inną mentalnością, innym sposobem postrzegania świata za pomocą języka? W przypadku tekstu popularnonaukowego, którego fragmenty tłumaczyłam, owe metody celowego i strategicznego wprowadzania obcych realiów bądź też wzmacniania zawartych w nich „sygnałów obcości” mogą być następujące (oczywiście są to wybrane przykłady):

- D u b l e t y w przypadku tłumaczenia dzieł literackich i nazw instytucji; nie zapominajmy, że mamy do czynienia z tekstem popularnonaukowym. Cytowanie wyłącznie oryginalnych form mija się z celem tworzenia 
właśnie takiego typu tekstu. Oczywiście zadanie tłumacza komplikuje w tym momencie tzw. norma lub uzus w cytowaniu odpowiednich nazw obcych. Otóż niezbędna okazuje się i w tym razem erudycja tłumacza. Imitation du Jésus-Christ nie można bowiem przetłumaczyć jako Naśladowanie Jezusa Chrystusa, lecz O naśladowaniu Jezusa Chrystusa (w takiej postaci tytuł ten funkcjonuje od wieków w Polsce), Le Christianisme raisonnable jako Chrześcijaństwo racjonalne (prawidłowa forma to Racjonalność chrześcijaństwa; tytuł francuski to skonwencjonalizowana forma angielskiego tytułu Reasonableness of Christianity. W polskiej literaturze spotykamy tłumaczenie z języka angielskiego), Confession d'un enfant du siècle oczywiście jako Spowiedź dziecięcia wieku itd. Czemu dublety wydają się atrakcyjniejsze w tekście przekładu? Po pierwsze właśnie dlatego, iż formy polskie mają często własną, opartą na tradycji formę i czytelnik polski, nawet znający język francuski, mógłby zostać wprowadzony w błąd lub niedoinformowany, po drugie, jeśli zadaniem przełożonego tekstu jest zachęcenie czytelnika do „zagłębiania” się w temat lub dziedzinę, oryginalne formy tytułów dzieł czy nazw instytucji mogą otworzyć mu drogę do lektury tekstów bardziej specjalistycznych. Jak daleko może posunąć się w tym przypadku tłumacz, to już materiał na osobny artykuł.

- E k s p li c y t a c j a (rozumiem ją jako wprowadzenie do TD dodatkowej informacji, także wyrażenie explicite tego, co w TW zostało wyrażone w sposób implicite); i tak np. procedura ta posłużyła mi do celowego przetłumaczenia wyrażenia "la foule des brassiers” (a przypomnijmy, że „brassiers” oznaczało niegdyś we Francji robotników najemnych podejmujących pracę u innych rolników) jako „brassierzy - robotnicy rolni najmujący się do pracy fizycznej u innych rolników”. Zamieściłam zatem, za pomocą procedury eksplicytacji, neologizm słowotwórczy (spotykany zresztą w niektórych źródłach polskich); dzięki temu działaniu udostępniłam czytelnikowi TD możliwość poznania leksemu, który nie ma swego odpowiednika w języku polskim. Z kolei fragment: „missions des eudistes [...] et des montfortains”, został przez mnie przełożony jako „misje prowadzone przez stowarzyszenie Św. Eudesa (eudystów) i kongregację Św. Ludwika Marii Grignon de Monfort (monfortanów)". Dosłowne tłumaczenie polskie było oczywiście możliwe. Wydaje się jednak, iż eksplicytacja zawartych w przymiotnikach francuskich informacji - a więc podanie czytelnikowi polskiemu nie tylko nazw kongregacji (co wydaje się czytelne wyłącznie dla specjalistów lub znawców dziedziny), lecz także imion ich założycieli - zwiększa wiedzę czytelnika polskiego (niespecjalisty), a także służy wzmocnieniu 
sygnałów obcości (w wyniku tłumaczenia otrzymujemy bowiem „podwójne" obce realia).

- Z a p o ż y c z e n i a: z pewnością z pojęciem „zapożyczeń” związane jest także pojęcie „nieprzekładalności”. W tym momencie wypada zwrócić uwagę na pewien podział, którym podlegają zdefiniowane przez nas obce realia; problem nieprzekładalności dotyczy bowiem tylko jednej z nich. Grupę pierwszą stanowią realia, które jednak są zbudowane z jednostek JD, a pozostają obcymi realiami na poziomie denotatu lub konotatu: „la III République” zostanie bowiem przetłumaczona jako „III Republika”, a zatem będzie stanowiła obce realia $\mathrm{z}$ racji tego, co rozumiemy pod pojęciem „III Republika” i z czym ona nam się kojarzy. I wreszcie drugą grupę stanowią realia rzeczywiście nieprzetłumaczalne: „brassiers” lub „tiers-mondisme", które po prostu nie mają swych odpowiedników w języku polskim. Tłumacz zmuszony jest zatem posłużyć się zapożyczeniem (i będzie to działanie w kierunku egzotyzacji TD), o ile nie wybierze procedury udomowienia. Tekst przekładu wydaje się typem tekstu, który w szczególny sposób sprzyja zapożyczeniom jako środkom do poznania „Innego”. Z pewnością można by wygłosić sąd przeciwny, to znaczy taki, który twierdziłby, iż tekst przekładu powinien dążyć do minimalizacji obco brzmiących terminów właśnie dlatego, że jest on tekstem popularnonaukowym, a nie specjalistycznym. Wydaje mi się jednak, iż biorąc do ręki tekst $z$ dziedziny nauk humanistycznych, siłą rzeczy mocno zakorzeniony w pojęcia uwarunkowane kulturowo, czytelnik jest przygotowany na stawianie czoła „obcym realiom” i będzie uważał je za wartość, za środek do głębszego poznania obcej mu kultury.

\section{Literatura}

Bastin, G., 1990, „Traduire, adapter, réexprimer”, Meta: Journal des traducteurs, volume 25, numéro 3, Montréal.

Dąmbska-Prokop, U., 2000, Mała Encyklopedia Przekładoznawstwa, red. U. Dąmbska-Prokop i in., Częstochowa.

Hejwowski, K., 2004, Kognitywno-komunikacyjna teoria przekładu, Warszawa.

Lederer, M., 1994, La traduction aujourd'hui, Paryż.

Lewicki, R., 2000, Obcość w odbiorze przekładu, Lublin. 
Lotman, Y. M., 1992, „Le phénomène de la culture”, Meta: Journal des traducteurs, volume 37, numéro 1, Montréal.

Pieńkos, J., 2003, Podstawy przekładoznawstwa. Od teorii do praktyki, Zakamycze.

Ping, K., 1999, „Cultural presuppositions and misreadings”, Meta: Journal des traducteurs, volume 44, numéro 1, Montréal.

Pisarska, A., Tomaszkiewicz, T., 1996, Współczesne tendencje przekładoznawcze, Poznań.

Valero-Garces, C., 1995, „Modes of translating culture: ethnography and translation”, Meta: Journal des traducteurs, volume 40, numéro 4, Montréal.

Xinmu, Z., 1999, „Les signes sociaux et leur traduction”, Meta: Journal des traducteurs, volume 44, numéro 1, Montréal.

\section{Transfer of cultural specific items: the example of a popular science text Definitions and basic problems}

(summary)

In Poland, the term cultural specific item does not have a coherent and extensive definition. Most researchers agree about its close relation with what we perceive as the culture of a given country. Thus, culturally marked units become cultural specific items and in this particular context we should rather refer to their transfer (i.e. transfer and/or translation) than translation. A popular science text poses a genuine challenge for the translator, as it might occur that the cultural specific items constituting source text implicit knowledge (of the target audience as assumed a priori by the author) may distort the comprehension of the text which is by definition aimed at non-experts. 